\title{
Gopal Das
}

\section{3-1991}

\section{A Remembrance}

When I close my eyes and think of Gopal Das I see him in the dimly lit Neuroanatomy teaching lab on the second floor of Lily Hall at Purdue, standing behind an overhead projector, his face eerily illuminated by the light from the vents around the projector, describing the connections of brainstem, enwrapping each concept of connectivity, cytology and cytoarchitecture in his own form of poetry, hypnotically bringing a peculiar aggregation of Latin names and obscure drawings together, creating a dynamic brain in our minds. Gopal's death in 1991 following a heart attack deprived Purdue of a talented teacher, deprived Science of a unique talent, and deprived many of us of a mentor we had suspected of being immortal. His work, of course, stands as an eternal memorial to his genius, insight, and his painstakingly systematic and straightforward approach to science. In his twenty years on the faculty of the Department of Biological Sciences at Purdue, nine of his students earned Ph.D.s, another seven received Masters degrees, numerous undergraduate students performed Honors research in his laboratory, and a score of other students asked him to serve on their graduate committees. The contributors to this volume are all, like myself, former Ph.D. students who worked under his direction.

Gopal was born in Northeastern India in 1933 and his family moved south from their ancestral home near Afghanistan in what is now Pakistan, to Bombay during the time of India's partition after the second world war. During one of several periods of adversity in my own graduate days Gopal confided the following story to me. When he showed up for the first day of school in Bombay he was asked his name by the school officials, themselves all native to the Bombay area. He gave it, a long name renowned in his homeland but ridiculed down south as being "the name for a goat". He was given a new surname, which he kept and has been known by in scientific circles since. He advised me that one could persevere through even worse adversity than I was facing if one could achieve the right perspective. He clearly did more than persevere during his career.

$\mathrm{He}$ earned his Ph.D. at Boston University in 1965 under Dr. Joseph Altman and studied under Dr. Walle Nauta and many of the other forefathers of modern Neuroanatomy. He went to the Max Planck Institute in Munich, Germany to work with Georg Kreutzberg, who became one of Gopal's dearest friends. Gopal rejoined Joe Altman and moved with him as an assistant professor to the Department of Biological Sciences at Purdue in 1968. He continued collaborative work on neurogenesis but also began the pursuit of what was to become his passion and obsession, neural tissue transplantation. He told the story that as a postdoc he had a notion that it might be possible to restore damaged brain circuitry by transplanting slabs of developing brain tissue, inserting them much as one would insert an integrated circuit board into a computer. Early efforts (Das and Altman, 1971) transplanting cerebellar primordia from a ${ }^{3} \mathrm{H}$ thymidine labeled donor to a non-labeled neonatal host taught them that nervous system repair through the use of transplants was not to be as easy as upgrading a computer's memory This work began his characterization of the principles and properties of neural tissue transplantation, work which would become the foundation for a field of research that saw exponential growth within a decade.

He pursued transplantation in his own laboratory with his graduate students as well as his wife and assistant Kunda, working always as a team while performing surgeries. A hierarchy developed in which the most senior student was accorded the privilege of assisting with surgery, observing him 
perform through the observation tube of the 'scope, and the more junior students were relegated to performing the less glamorous jobs of anesthesia, suturing, or shuttling cages between the surgery and the animal rooms. Gopal remained a "hands on" scientist for the rest of his life. Both his skill and his enthusiasm for research were clearly evident to all who worked with him. It is probably fitting that he is best remembered and most often cited for the two papers that described the promise, the potential, and the technique of transplantation (Das et al. 1974, 1979). During the early period in his laboratory he and his students Howard Nornes, Bill Anderson, Mike Pfaffenroth, and Pat McAllister pursued other interests including normal and abnormal nervous system development, but over time his laboratory became the transplantation laboratory. By the time I joined the gorup in 1978 the focus was almost exclusively on transplantation. Although his technical papers may have been more often cited, work performed during the middle era in his laboratory, defining properties of transplant growth and connectivity with Brian Hallas and Monica Oblinger, were perhaps the most important works to come out of the laboratory. These studies made clear both the potential and the limitations of the transplantation technique. This work was augmented by studies performed with John Houle on the survivability and transplantability of cryopreserved embryonic neural tissue, with Jane Brasko on the development of transplanted embryonic and postnatal tissues, and the basic survivability properties of tissues from all regions of the neuraxis, a project to which virtually every graduate student who ever passed through his laboratory contributed in some way. The later phase of Dr. Das's work, in which he was assisted by students Prashant Rai and Maureen Reidel, was characterized by an intense focus on the potential of embryonic nervous tissue for repair of spinal cord injury. Although he first performed such studies in the mid-70s, he became more and more committed to studying the problems and possible solutions to spinal cord injury as time went on. He had not turned his back, however, on his studies defining the basic properties of transplant survival and growth. Dr. Altman met Gopal about a week prior to his death and found that Gopal was very enthusiastic about preliminary results he had obtained using amniotic fluid for enhancing the survival and differentiation of transplanted embryonic neuroblasts, most of which otherwise die following transplantation. Given the resurgence of interest in neurotrophic factors today, this observation may also prove to open another field of study, helping to bring Gopal Das's vision of replacement of damaged circuitries that much closer to reality.

Although Gopal was very serious and dignified in his bearing, he was a complex, deeply thoughtful man who also had another side that was almost whimsical. My first indication that the man may be human was when, as a young graduate student privileged to accompany him to the Anatomy meeting in New Orleans in 1981, I witnessed his smile as Dr. Jerry Bernstein bestowed a bear hug that not only engulfed him but, I feared, might have cracked several ribs as well. Although a vegetarian, he had a secret hankering for Big Macs and most of his later students dined out with him beneath the golden arches at scientific meetings. Gopal could be difficult, as all of his students can attest, and was often critical of the work of other scientists, sometimes overly so, but where his friendship ran it was deep, as his good friends and long time collaborators, including Bob Wallace and others, will attest

$\mathrm{He}$ is mourned by his family: Kunda, his daughter Shonu and his son Ravi, and all his friends, and missed by many others: both those who knew of his work and those who will labor in fields where his enlightenment would have continued to lead the way. On rare occasions Gopal would find sources of inspiration and gems of wisdom from the most unlikely places and share them with his students. $\mathrm{He}$ was an avid fan of the old Dick Van Dyke show and his favorite episode was one in which the character Rosemarie related an incident, acted out by the characters of the show, which afterwards was remembered differently by everyone else involved. She allowed that some of the others may have more accurately portrayed the events which took place, but that since she was the one that got to write the story, hers would be the truth others would remember. Gopal's version of the truth will survive him in his scientific writings, a tale that will be worth reading for a long time to come. The best 
tribute we, his former students, can make to him is our own work, using the gifts and talents that he helped nurture. I am sure he would have told it differently, but the telling of the tale was left to me. I miss him, think of him often, and will remember him always.

\section{PROSPERO, O PROSPERO}

The riddle shall lead through maze of all choice patterning answers from symbols unsaid, released from the night within the small voice "What stays behind now yet goes on ahead?" My puzzle I keep, I preach not its way, learners may find ways unknown to me still, far be it from me to decide and say "So shall it be" and impose thus my will; For I remember the tales I've been told, their echoes still sound "There's more to the truth" than rumors I've heard that some day we'll hold volumes we'll value much more than our youth; Cast from deepest truths these tales may show humors by which our selves we'll know.

Douglas T. Ross, Ph.D. 6 September 1994
STUDENTS RECEIVING DEGREES UNDER PROFESSOR GOPAL D. DAS

\begin{tabular}{|l|l|}
\hline B.S. Honors Theses & Date \\
\hline Gordon Greenman & 1973 \\
\hline Bradley Black & 1973 \\
\hline Mark Harshman & 1973 \\
\hline Larry Berte & 1973 \\
\hline Patricia Kotylo & 1975 \\
\hline Gayle Winters & 1975 \\
\hline Rita Huff & 1976 \\
\hline Manfred Muller & 1978 \\
\hline Mary K. Hill & 1981 \\
\hline Jose Aleman-Gomez & 1983 \\
\hline Angel Hernandez & 1991 \\
\hline Cynthia Huan & 1992 \\
\hline
\end{tabular}

\begin{tabular}{|l|l|}
\hline Masters Theses & Date \\
\hline Gary Lammert & 1973 \\
\hline Brian H. Hallas & 1976 \\
\hline John D. Houlé & 1977 \\
\hline Monica M. Oblinger & 1978 \\
\hline Andrew Della-Colletta & 1980 \\
\hline Jane Brasko & 1981 \\
\hline Cheryl M. Chanaud & 1984 \\
\hline
\end{tabular}

\begin{tabular}{|l|l|}
\hline Ph.D. Dissertations & Date \\
\hline William J. Anderson & 1974 \\
\hline Howard O. Nornes & 1975 \\
\hline James P. McAllister III & 1976 \\
\hline Michael J. Pfaffenroth & 1977 \\
\hline Brian H. Hallas & 1979 \\
\hline John D. Houlé & 1981 \\
\hline Monica M. Oblinger & 1981 \\
\hline Douglas T. Ross & 1983 \\
\hline Maureen Reidl & 1991 \\
\hline Prashant Rai & 1992 \\
\hline Jane Brasko & 1993 \\
\hline
\end{tabular}




\section{A CHRONOLOGICAL BIBLIOGRAPHY OF GOPAL D. DAS}

1964

Altman JA, Das GD. Autoradiographic and histological investigation of changes in the visual system of rats after unilateral enucleation. Anat Rec 1964; 148: 535545.

Altman JA, Das GD. Autoradiographic examination of the effects of enriched environment on the rate of glial multiplication in the adult rat brain. Nature 1964; 204 : 1161-1163.

1965

Altman JA, Das GD. Autoradiographic and histological evidence of postnatal hippocampal neurogenesis in rats. J Comp Neurol 1965; 124: 319-336.

Altman JA, Das GD. Postnatal origins of microneurons in the rat brain. Nature $1965 ; 207$ : 953-956.

\section{6}

Altman JA, Das GD. Autoradiographic and histological studies of postnatal neurogenesis I. A longitudinal investigation of the kinetics, migration and transformation of cells incorporating tritiated thymidine in neonate rats with special reference to postnatal neurogenesis in some brain regions. J Comp Neurol 1966; 126: 337-390.

Altman JA, Das GD. Behavioral manipulations and protein metabolism of the brain: I. Effects of motor exercise on the utilization of leucine- $\mathrm{H}^{3}$. Physiol Behav 1966; 1: 105-108.

Das GD, Altman JA. Behavioral manipulations and protein metabolism of the brain: II. Effects of restricted and enriched environments on the utilization of leucine- $H^{3}$. Physiol Behav 1966; 1: 109-110.

Altman JA, Das GD, Chang J. Behavioral manipulations and protein metabolism of the brain: III. Effects of visual training on the utilization of leucine- $\mathrm{H}^{3}$. Physiol Behav 1966; 1: 111-115.

\section{7}

Das GD, Kreutzberg GW. Postnatal differentiation of the granule cells in the hippocampus and cerebellum: a histochemical study. Histochemie 1967; 10: 246-260.

Altman JA, Das GD. Postnatal neurogenesis in the guinea pig. Nature 1967; 214: 1098-1101.

\section{8}

Das GD, Kreutzberg GW. Evaluation of interstitial nerve cells in the central nervous system. A correlative study using acetylcholinesterase and Golgi techniques. Ergeb Anat Entw 1968; 41: 1-69.

Altman JA, Das GD, Anderson WJ. Effects of infantile handling on the morphological development of the rat brain: an exploratory study. Dev Psychobiol 1968; 1 : 10-20.

Altman JA, Wallace RB, Anderson WJ, Das GD. Behaviorally induced changes in the length of cerebrum in rats. Dev Psychobiol 1968; 1: 112-117.

\section{9}

Wallace RB, Altman JA, Das GD. An autoradiographic and morphological investigation of the postnatal development of the pineal body. Am J Anat 1969; 126: 175-184.

1970

Das GD. An evaluation of the interstitial nerve cells in the cerebellum. Z Anat Entw 1970; 131: 283-290.

Das GD, Altman JA. Postnatal neurogenesis in the caudate nucleus and nucleus accumbens septi in the rat. Brain Res 1970; 21: 122-127.

Altman JA, Das GD. Postnatal changes in the concentration and distribution of cholinesterase in the cerebellar cortex of rats. Exp Neurol 1970; 28: 11-34.

1971

Das GD. Projections of the interstitial nerve cells surrounding the globus pallidus: A study of retrograde changes following cortical ablations in rabbits. Z Anat Entw 1971; 133: 135-160.

Das GD. Experimental studies on the postnatal development of the brain. I. Cytogenesis and morphogenesis of the accessory fascia dentata following hippocampal lesions. Brain Research 1971; 28: 263-282.

Das GD. Premature cessation of neurogenesis and gliogenesis in rats showing runting syndrome. Virchows Arch Abt B Zellpath 1971; 9: 58-74.

Das GD, Altman J. Postnatal neurogenesis in the cerebellum of the cat and tritiated thymidine autoradiography. I. The external granule cell layer and the transitional molecular layer. Brain Res 1971; 30: 323-330.

Das GD, Altman J. The fate of transplanted precursors of nerve cells in the cerebellum of young rats. Science 1971; 173: 637-638.

Altman JA, Das GD, Sudarshan K. The influence of nutrition on neural and behavioral development. I. 
Critical review on some data on the growth of the body and the brain following dietary deprivation during gestation and lactation. Dev Psychobiol 1971; 3: 281301.

Altman JA, Das GD, Sudarshan K, Anderson WJ. The influence of nutrition on neural and behavioral development. II. Growth of body and brain using different techniques of undernutrition. Dev Psychobiol 1971; 4: 55-70.

Altman JA, Sudarshan K, Das GD, McCormick N, Barnes $D$. The influence of nutrition on neural and behavioral development. III. Development of some motor, particularly locomotion, patterns during infancy. Dev Psychobiol 1971; 4: 97-114.

1972

Das GD, Altman J. Studies on the transplantation of developing neural tissue in the mammalian brain. I. Transplantation of cerebellar slabs into the cerebellum of neonate rats. Brain Res 1972; 38: 233-249.

Das GD. Influences of the pia mater on the precursors of nerve cells. Z Anat Entwickl-Gesch 1972; 138: 227 240.

Das GD, Hine RJ. Nature and significance of spontaneous degeneration of axons in the pyramidal tract. $Z$ Anat Entwickl-Gesch 1972; 136: 98-114.

Das GD, Nornes HO. Neurogenesis in the cerebellum of the rat: An autoradiographic study. Z Anat EntwicklGesch 1972; 138: 155-165.

Das GD, Pfaffenroth M. Effects of ethyl-nitrosourea on the devclopment of the brain. Experientia 1972; 28: 10761077.

Nornes HO, Das GD. Temporal pattern of neurogenesis in spinal cord: Cytoarchitecture and directed growth of axons. Proc Natl Acad Sci USA 1972; 69: 1962-1966.

1973

Das GD. Transplantation of cerebellar tissue in the cerebellum of neonate rabbits. Brain Res 1973; 50: 170-173.

Das GD, Nornes HO, Hine RJ, Pfaffenroth MJ. Experimental studies on the postnatal development of the brain. II. Cytoarchitectural regeneration in the developing cerebellum of the rabbit. T-I-T J Life Sci 1973; 3: 29-65.

Das GD, Nornes HO, Hine RJ, Pfaffenroth MJ. Experimental studies on the postnatal development of the brain. II. Cytoarchitectural regeneration in the developing cerebellum of the rabbit. T-I-T J Life Sci 1973; 3: 29-65.
1974

Das GD. Transplantation of embryonic neural tissue in the mammalian brain. I. Growth and differentiation of neuroblasts from various regions of the embryonic brain in the cerebellum of neonate rat. T-I-T J Life Sci 1974; 4: 93-124.

Das GD, Lammert GL, McAllister JP. Contact guidance and migratory cells in the developing cerebellum. Brain Res 1974; 69: 13-29.

Hine RJ, Das GD. Neuroembryogenesis in the hippocampal formation of the rat. An autoradiographic study. Z Anat Entwickl-Gesch 1974; 144: 173-186.

Nornes HO, Das GD. Temporal pattern of neurogenesis in spinal cord of rat. I. An autoradiographic study - Time and sites of origin and migration and settling patterns of neuroblasts. Brain Res 1974; 73: 121-138.

Pfaffenroth MJ, Das GD. Heterotopic cell nests in the developing rat cerebellum. Acta Neuropathol 1974; 30 : $1-9$.

Pfaffenroth MJ, Das GD, McAllister JP. Teratologic effects of ethyl-nitrosourea on brain development in rats. Teratology $1974 ; 9$ : 305-316.

1975

Das GD. Transient cytoplasmic bridges among cells of developing cerebellum: A possible mode of induction for cell differentiation. Cell Differentiation 1975; 3 : 371-377.

Das GD. Differentiation of dendrites in the transplanted neuroblasts in the mammalian brain. In: Kreutzberg GW, ed, Advances in Neurology: Physiology and Pathology of Dendrites, Vol. 12. New York: Raven Press, 1975; pp. 181-199.

Das GD. Resting and reactive macrophages in the developing cerebellum: An experimental ultrastructural study. Virchows Archiv B Cell Pathology 1976; 20: 287-298.

Das GD. Gitter cells and their relationship to macrophages in the developing cerebellum: An electron microscopic study. Virchows Archiv B Cell Pathology 1976; 20: 299-305.

Das GD. Differentiation of Bergmann glia cells in the cerebellum: A Golgi study. Brain Res 1976; 110: 199213.

Das GD, Pfaffenroth MJ. A further note on the presence of the endogenous macrophages in the developing cerebellum. Virchows Archiv B Cell Pathology 1976: 22: 299-304. 
Das GD. Membrane-fusions and cytoplasmic bridges in the cells of the developing cerebellum. Cell Tissue Res 1977; 176: 475-492.

Das GD. Gliogenesis during embryonic development of the rat. Experientia 1977; 33: 1648-1649.

Das GD. Experimental analysis of embryogenesis of cerebellum in rat. I. Subnormal growth following Xray irradiation on day 15 of gestation. J Comp Neurol 1977; 176: 419-434.

Das GD. Experimental analysis of embryogenesis of cerebellum in rat. II. Morphogenetic malformations following X-ray irradiation on day 18 of gestation. J Comp Neurol 1977; 176: 435-452.

Das GD. Induction of mitosis in the differentiating Purkinje cells of the cerebellum. Acta Anatomica 1977; 97: 435-442.

Das GD. Binucleated neurons in the central nervous system of the laboratory animals. Experientia 1977; 33: $1179-1180$.

Das GD, Pfaffenroth MJ. Experimental studies on the postnatal development of the brain. III. Cerebellar development following localized administration of ENU. Neuropathology and Applied Neuro-biology 1977; 3: 191-212.

McAllister JP, Das GD. Neurogenesis in the epithalamus, dorsal thalamus and ventral thalamus of the rat: An autoradiographic and cytological study. J Comp Neurol 1977 ; $172: 647-686$.

1978

Das GD. Premature death of Purkinje cells following lowlevel X-ray irradiation during embryonic development. Acta Anatomica 1978; 101: 225-233.

Das GD, Hallas BH. Transplantation of brain tissue in the brain of the adult rat. Experientia 1978; 34: 13041306.

Hallas BH, Das GD. N-Ethyl-N-nitrosourea-induced teratogenesis in the brain in the rat. J Neurol Sci 1978; 39: 111-122.

Morre DM, Kirksey A, Das GD. Effects of vitamin $B_{6}$ deficiency on the developing central nervous system of the rat. Gross measurements and cytoarchitectural alterations. J Nutr 1978; 108: 1250-1259.

Morre DM, Kirksey A, Das GD. Effects of vitamin $\mathrm{B}_{6}$ deficiency on the developing central nervous system of the rat. Myelination. J Nutr 1978; 108: 1260-1265.

1979

Das GD. Gliogenesis and ependymogenesis during embryonic development of the rat. An autoradiographic study. J Neurol Sci 1979; 43: 193-204.
Das GD, Hallas BH, Das KG. Transplantation of neural tissues in the brain of laboratory mammals: Technical details and comments. Experientia 1979; 35: 143-153

Hallas BH, Das GD. An aberrant nucleus in the telencephalon following administration of ENU during neuroembryogenesis. Teratology 1979; 19: 159-164.

Pfaffenroth MJ, Das GD. N-Ethyl-N-nitrosourea-induced spinal tumors in an inbred strain of $\mathrm{W}$-albino rats. J Natl Cancer Inst 1979; 63: 647-650.

\section{0}

Das GD, Hallas BH, Das KG. Transplantation of brain tissue in the brain of rat. I. Growth characteristics of transplants from embryos of different ages. Am J Anat 1980; 158: 135-145.

Hallas BH Das GD, Das KG. Transplantation of brain tissue in the brain of rat. II. Growth characteristics of transplants in the hosts of different ages. Am J Anat 1980; 158: 147-159.

Hallas BH, Oblinger MM, Das GD. Heterotopic neural transplants in the cerebellum of the rat: Their afferents. Brain Res 1980; 196: 242-246.

Houlé JD, Das GD. Freezing and transplantation of brain tissue in rats. Experientia 1980; 36: 1114-1115.

Houlé JD, Das GD. Freezing of embryonic neural tissue and its transplantation in the rat brain. Brain Res 1980; 192: 570-574.

Oblinger MM, Hallas BH, Das GD. Neocortical transplants in the cerebellum of the rat: Their afferents and efferents. Brain Res 1980; 189: 228-232.

1981

Oblinger MM, Das GD. Neurogenesis in the brain stem of the rabbit. An autoradiographic study. J Comp Neurol 1981; 197: 45-62.

1982

Das GD. Extraparenchymal neural transplants: Their cytology and survivability. Brain Res 1982; 241 : 182 186.

Das GD, Ross DT. Stereotaxic technique for transplantation of neural tissues in the brain of adult rats. Experientia 1982; 38: 848-851.

Oblinger MM, Das GD. Connectivity of neural transplants in adult rats: Analysis of afferents and efferents of neocortical transplants in the cerebellar hemisphere. Brain Res 1982; 249: 31-49.

Wallace RB, Das GD. Behavioral effects of CNS transplants in the rat. Brain Res 1982; 243: 133-139. 
Das GD. Neural transplantation in the spinal cord of the adult mammals. In: Kao CC, Bunge RP, eds, Reconstruction of the Spinal Cord. New York: Raven Press, 1983; pp. 367-396.

Das GD, Houlé JD, Brasko J, Das KG. Freezing of neural tissues and their transplantation in the brain of the rat: Technical details and histological observations. J Neurosci Meth 1983; 8: 1-15.

Das GD. Neural transplantation in mammalian brain: Some conceptual and technical considerations. In: Wallace RB, Das GD, eds, Neural Tissue Transplantation Research. Berlin-Heidelberg-New York: Springer-Verlag, 1983; pp. 1-64.

Das GD. Neural transplantation in the spinal cord of the adult rats: Conditions, survival, cytology and connectivity of the transplants. J Neurol Sci 1983; 62: 191-210.

Das GD, Das KG, Brasko J, Aleman-Gomez J. Neural transplants: Volumetric analysis of their growth and histopathological changes. Neurosci Lett 1983; 41: 7379.

Albert EN, Das GD. Neocortical transplants in the rat brain: An ultrastructural study. Experientia 1983; 4: 294-298.

Houlé JD, Das GD. Permanent alterations in the rat spinal cord following prenatal exposure to $\mathrm{N}$-ethyl-Nnitrosourea. Brain Res Bull 1983; 10: 839-845.

Oblinger MM, Das GD. Connectivity of neural transplants in the cerebellum: A model of developmental differences in neuroplasticity. In: Wallace RB, Das GD, eds, Neural Tissue Transplantation Research New York: Springer-Verlag, 1983; pp. 105-134.

1984

Das GD. Neural transplantation in the spinal cord and its functional significance. In: Rossier A, Radaelli E, Radaelli T, eds, Paraplegia and Tetraplegia. Milan, Italy: Libreria Scientifica gia GHEDINI s.r.l., 1984; pp. 23-54.

Houle JD. Das GD. Tissue repair in the embryonic spinal cord following exposure to N-ethyl-N-nitrosourea. Int J Dev Neurosci 1984; 2: 1-11.

\section{5}

Das GD. Intraparenchymal transplantation. In: Björklund A, Stenevi U, eds, Neural Grafting in the Mammalian CNS. Amsterdam: Elsevier, 1985; pp. 23-30.

Das GD. Development of neocortical transplants. In: Björklund A, Stenevi U, eds, Neural Grafting in the Mammalian CNS. Amsterdam: Elsevier, 1985; pp. 101-123.
Das GD. Histopathology of neural transplants and host brain. In: Processes of Recovery from Neural Trauma, Exp Brain Res, 1986; Suppl. 13: 88-106.

Das GD. Growth and development of neural transplants: Some quantitative parameters. In: Processes of Recovery from Neural Trauma, Exp Brain Res, 1986; Suppl. 13: 333-350.

Das GD. Neural transplantation in spinal cord under different conditions of lesions and their functional significance. In: Das GD, Wallace RB, eds, Neural Transplantation and Regeneration. New York: Springer-Verlag, 1986; pp. 1-66.

Das GD, Ross DT. Neural transplantation: Autoradiographic analysis of histogenesis in neocortical transplants. Int J Dev Neurosci 1986; 4: 69-79.

Ross DT, Das GD. Regenerative growth of retinofugal axons into and through neocortical transplants following transection of the optic tract in adult rats. In: Das GD, Wallace RB, eds, Neural Transplantation and Regeneration. New York: Springer-Verlag, 1986; pp. 181-228

1987

Das GD. Neural transplantation in normal and traumatized spinal cord. In: Cell and Tissue Transplantation into the Adult Brain. Ann NY Acad Sci, 1987; 495: 53-70.

Chanaud CM, Das GD. Growth of neural transplants: Effects of initial volume, growth potential and fresh vs. freezing of tissues. Neurosci Lett, 1987; 80: 127-133.

\section{8}

Predy R, Malhotra SK, Das GD. Enhanced expression of a protein antigen (JI-31 Antigen, 30 Kilodaltons) by reactive astrocytes in lacerated spinal cord. J Neurosci Res 1988; 19: 397-404.

\section{9}

Das GD. Perspectives in anatomy and pathology of paraplegia in experimental animals. Brain Res Bull 1989; 22: 7-32.

Das GD, Das KG, Brasko J, Reidl M, Rai P, Rajeswari V. Spinal traumas: Some postoperative complications in experimental animals. Brain Res Bull 1989; 22: 33-37.

1990

Das GD. Neural transplantation: An historical perspective. Neurosci Biobehav Rev 1990; 14: 389 401 

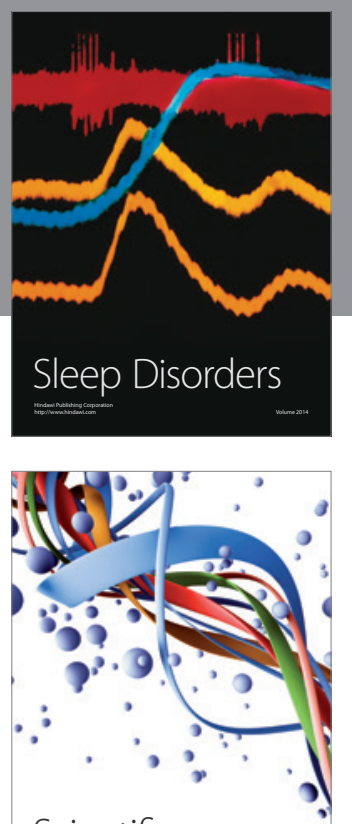

Scientifica
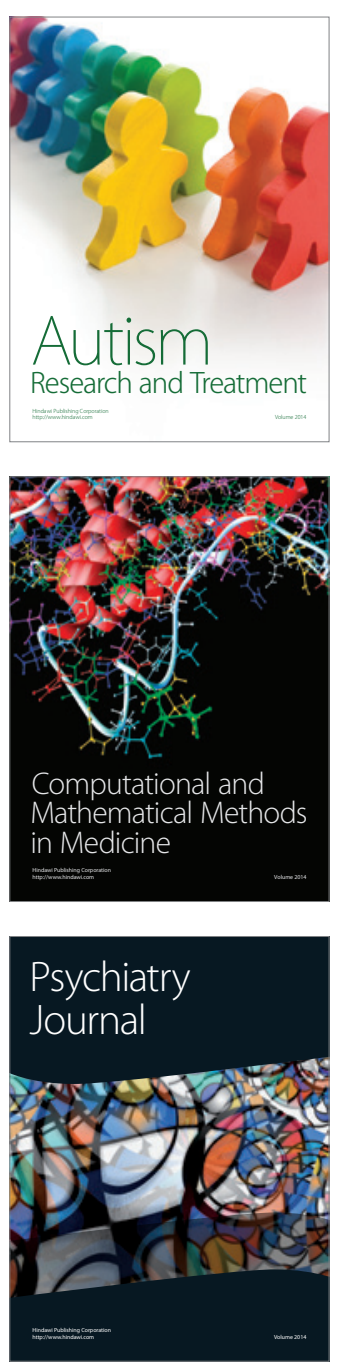
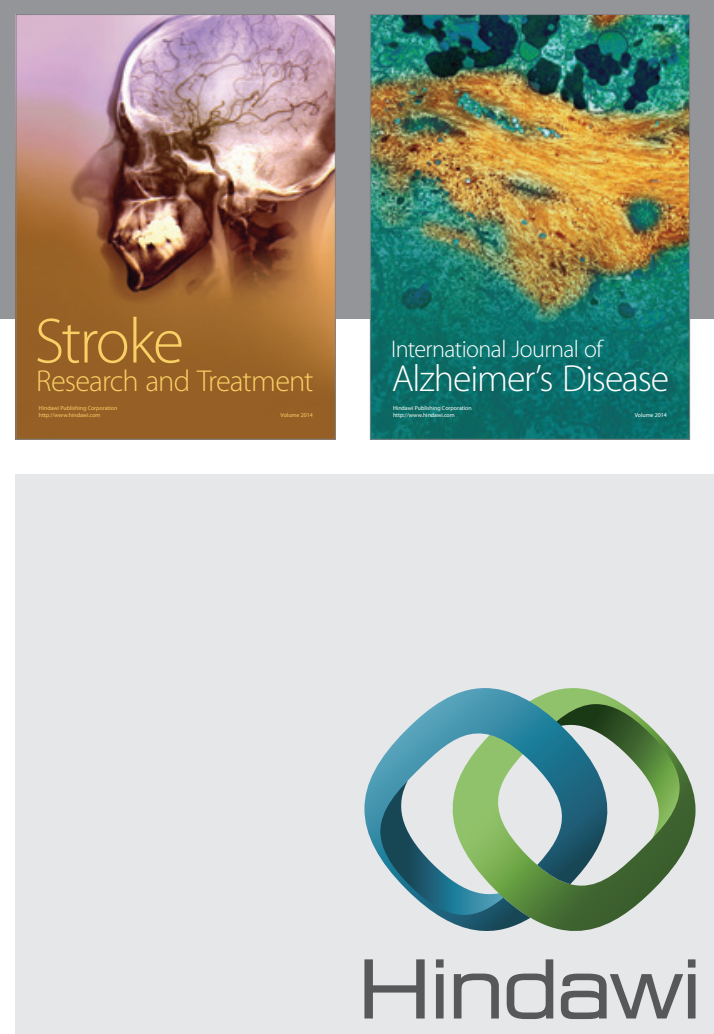

Submit your manuscripts at

http://www.hindawi.com
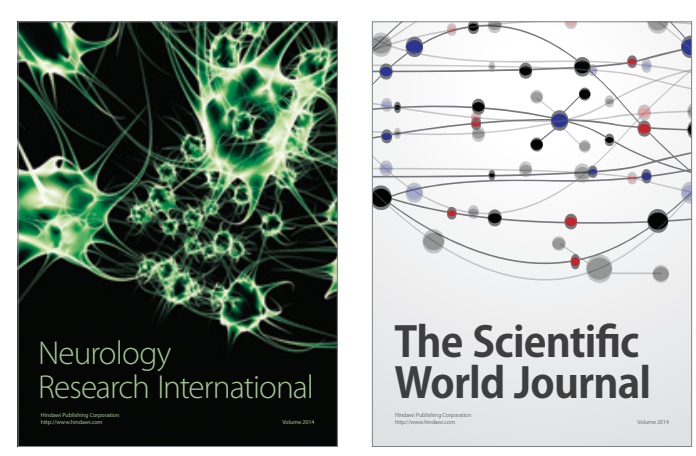

The Scientific World Journal

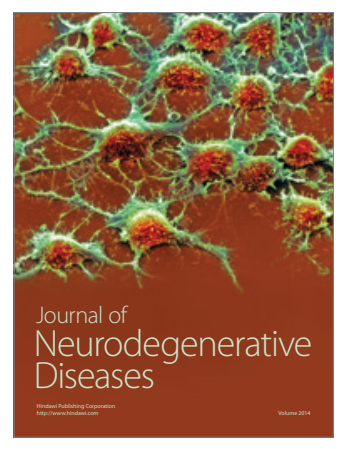

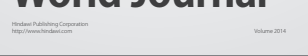

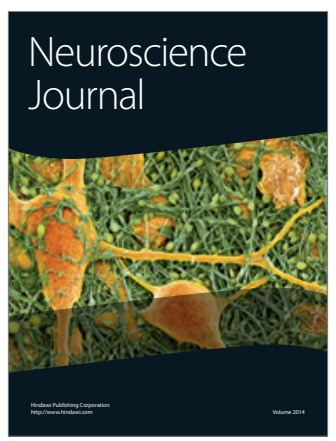

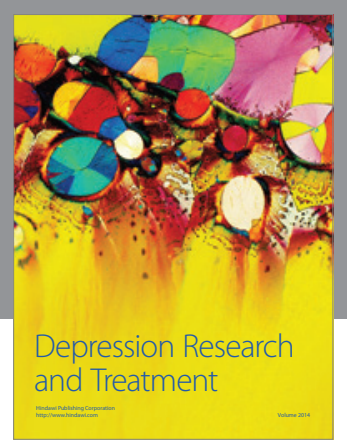
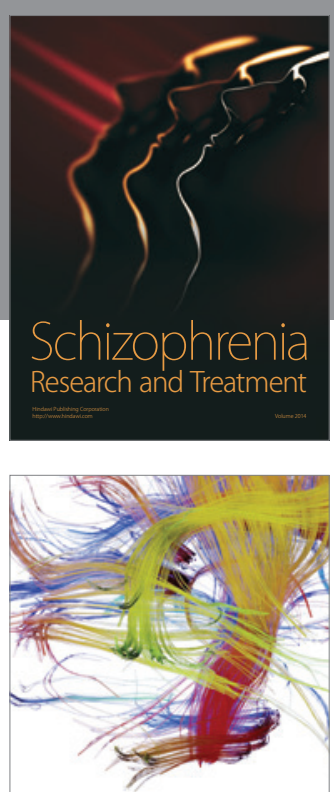

Brain Science

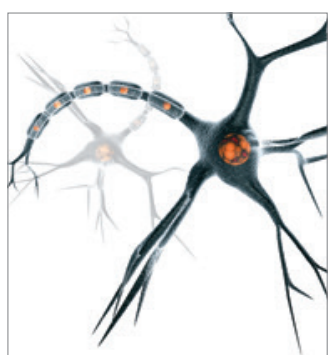

Neural Plasticity
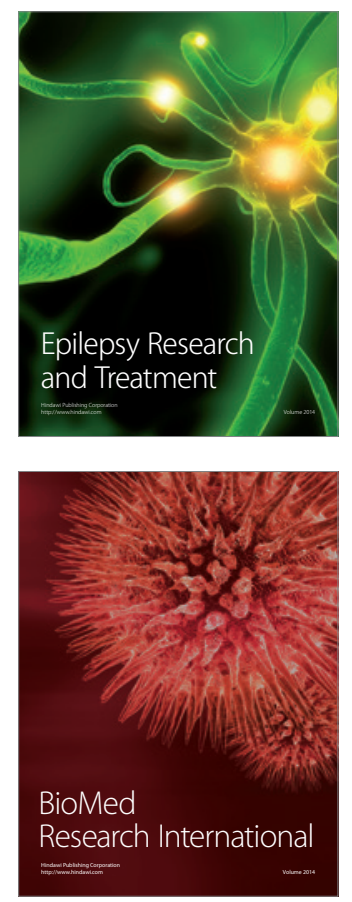

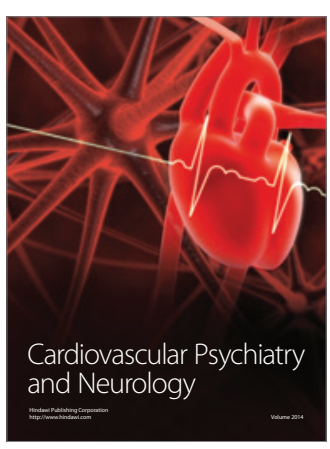

Parkinson's

Disease
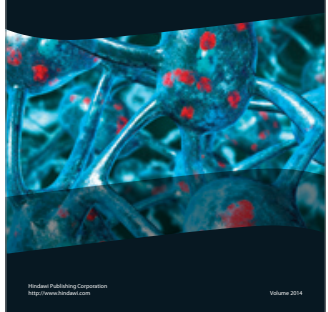